\title{
ON CAPILLARY RESISTENCE OF LEPROSY PATIENTS
}

\author{
Korehiro TAKEDA \\ (Dept. of Dermatology, School of Medicine Tokushima University) \\ (National Leprosarium Oshima Seishoen)
}

Capillary resistence (CR) was measured to investigate one of the skin functions of leprosy patients. GR was generally decreased, and as was very labile, it was apt to deviate from the physical functional range by single stimulation.

1) $\mathrm{CR}$ of the whole skin was, as Yokozeki reported, higher in the peripheries. It was lower in the flexular surface than in the extensor and in the upper than in the lower legs.

2) $\mathrm{CR}$ of leprosy patients in the subclavicular region was stronger than that of the normal. It was easily influenced by the time and the day.

3) By Erythema nodosum manifestation, CR decreased and was the lowest at the acme of the condition. In the fading stadium it was recovering after a temporary increase. By neuralgia CR increased.

4) Administration of hormons and autonomic nervous toxins produced in leprosy patients some different reactions from the normal people.

\section{癩患者の毛細血管抵抗に就いて}

\author{
武田已広 \\ 徳島大学医学部皮居泌尿器科教室 (指導 荒川忠良教授) \\ 国 立 療養所大島 青 松園（指導 野島泰治園長）
}

(昭 和 31 年 4 月 14 日受稿)

\section{緒 言}

皮周毛細血管の Per rhexin. Per diapedesin につい $\tau$, Von Borbély4), 戸塚・島内 ${ }^{22)}$, Franke, Alfeld,

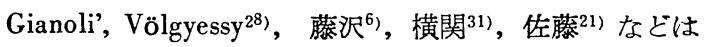
陰汇法により健唐者, 月経, 各種伝染病, 喘息, 皮唐疾 患々者を対象とし，また自律神経，ビタミン，ホルモン との関係及びこれに及ぼす物理化学的影響等を検討し, 霜患者のそれについては福田 ${ }^{7)}$, 宮尾・杉本・本多等 ${ }^{18}$ の報告がある。癩患者の皮膚, 筋肉或は骨質の未梢性萎 縮は勿論のとと末梢神経の機能的ないし器質的変化は当 然毛細血管の機能的或は器質的変化をもたらすものと考 えられる。従て今回は瀨患者の一つの機能的な面として 毛細血管抵抗（以下 C R と略記）をとりまげ，殊に C R の動態について観察を試みた。

実験方法

$\mathrm{CR}$ の測定: 内径 $2 \mathrm{~cm}$, 外径 $2.8 \mathrm{~cm}$, 深さ $1.5 \mathrm{~cm}$ の
吸角を有するいわしや製の Petechio-meter を使用した 縁にワセリンを塗布して測定部の皮㲊に密着させ， -10 $0 \mathrm{mmHg}$ で 1 分間吸引し，局所充血の消螁した後，辺 縁部の器械的損傷によると疑われる溢血斑を外し, 中 央 $1.8 \mathrm{~cm}$ 円内の溢血斑を硝子王診下に検查した。溢血斑 の認められぬ時は压を $10 \mathrm{mmHg}$ 宛増加して, 1 5 の溢 血斑出現の最大陰压 を以てその 皮眉毛細血管 抵抗とし た。但し今回の検査では部位的差異以外は左鎖骨下简を 被検部位とし，すべて区を一定とし，溢血斑数の增減で 判定した。

測定条件：被検者は脱衣することなく左鎖骨下を露出 させ坐位で測定した。測定室温は $13 \sim 22^{\circ} \mathrm{C}$ の間であり 気压前線の通過を避けたが，月間の变動を追求した時は 例外でめる。

被検者：正常血圧を有する23〜65 才のもので，現在 特に合併症の認められない者を選び，対照は月経中間期 にある健康な女子 44 名である。 


\section{実 験 成績}

\section{I 部位的差異}

健康者の全身 CR 分布について横関氏 ${ }^{311}$ は詳細に検討 しているので，私は合併症の認められないL 9名（21〜 50 才, 男子 5 名, 女子 4 名) $\mathrm{N} 4$ 名（19 35才, 男女各 2 名) の全身 15 ヶ所の CR を測定した (Tab. 1), 部位
により可なり個人差が見られる。とのことは図示すると 明らかである (Fig. 1)。前面では頸部及び鎖骨窩を，後 面では肩胛部及び頂部を最低とし，末梢に赴くについて 次第に高值に移行する。足底，手掌は余り高くて測定不 能，頸部は頂部より低く，前腕，下腿共に屈側は伸側よ り低い。

Tab. 1 部 位 的 差 異

\begin{tabular}{|c|c|c|c|c|c|c|c|c|c|c|c|c|c|c|c|c|}
\hline \multirow{2}{*}{\multicolumn{2}{|c|}{ 症例 }} & \multicolumn{10}{|c|}{ L $\quad(9$ 例 $)$} & \multicolumn{5}{|c|}{$\mathbf{N}$} \\
\hline & & $\begin{array}{c}21 \\
\hat{8} \\
\end{array}$ & $\begin{array}{c}25 \\
\hat{0} \\
\end{array}$ & $\begin{array}{c}28 \\
\hat{0} \\
\end{array}$ & $\begin{array}{c}33 \\
\hat{o} \\
\end{array}$ & $\begin{array}{c}34 \\
\text { 우 }\end{array}$ & $\begin{array}{c}35 \\
\text { 우 } \\
\end{array}$ & $\begin{array}{c}4.1 \\
\text { 우 } \\
\end{array}$ & $\begin{array}{l}49 \\
\hat{0} \\
\end{array}$ & $\begin{array}{c}50 \\
\text { 우 } \\
\end{array}$ & $\begin{array}{l}\text { 平 } \\
\text { 均 }\end{array}$ & $\begin{array}{c}19 \\
\text { 今 } \\
\end{array}$ & $\begin{array}{c}21 \\
\text { 우 }\end{array}$ & $\begin{array}{c}25 \\
\hat{8} \\
\end{array}$ & $\begin{array}{c}35 \\
\text { 오 } \\
\end{array}$ & $\begin{array}{l}\text { 平 } \\
\text { 均 } \\
\end{array}$ \\
\hline \multicolumn{2}{|c|}{ 煩 } & 15 & 16 & 16 & 14 & & & & & & 15.2 & 13 & 15 & & & 14.0 \\
\hline \multicolumn{2}{|c|}{ 頸 } & 7 & 7 & 8 & 7 & 6 & & & & & 7.0 & 7 & 7 & & & 7.0 \\
\hline \multicolumn{2}{|c|}{ 頂 } & 10 & 10 & 15 & 13 & 11 & & & & & 11.8 & 12 & 13 & & & 12.5 \\
\hline \multicolumn{2}{|c|}{ 鎖 骨下 } & 8 & 7 & 7 & 10 & 8 & 6 & 5 & 7 & 5 & 7.0 & 10 & 8 & 5 & 8 & 7.7 \\
\hline 肩 & 胛 & 8 & 9 & 11 & 13 & 9 & 6 & 7 & 8 & 10 & 9.0 & 8 & 6 & 8 & 8 & 7.5 \\
\hline \multicolumn{2}{|c|}{ 腰 } & 9 & 10 & 11. & 13 & 10 & 8 & 8 & 8 & 10 & 9.1 & 8 & 8 & 8 & 9 & 8.2 \\
\hline & 腹 & 12 & 13 & 13 & 17 & 14 & 16 & 15 & & & 14.3 & 13 & 15 & & & 14.0 \\
\hline 大 & 前 & 17 & 19 & 18 & 19 & 17 & & & & & 18.0 & 20 & 17 & & & 18.5 \\
\hline 腿 & 後 & 14 & 13 & 14 & 16 & 13 & & & & & 14.0 & 16 & 14 & & & 15.0 \\
\hline 下 & 前 & 25 & 27 & 27 & 25 & 28 & 27 & 30 & 27 & 27 & 27.0 & 30 & 25 & 25 & 26 & 26.5 \\
\hline 腿 & 後 & 24 & 24 & 23 & 23 & 24 & 24 & 25 & 25 & 24 & 24.0 & 26 & 20 & 22 & 21 & 22.1 \\
\hline 上 & 前 & 14 & 16 & 13 & 15 & 18 & & & & & 15.2 & 17 & 15 & & & 16.0 \\
\hline 腕 & 後 & 18 & 20 & 18 & 18 & 20 & & & & & 18.8 & 20 & 17 & & & 18.5 \\
\hline 前 & 風 & 15 & 14 & 14 & 13 & 13 & 14 & 13 & 10 & 14 & 13.3 & 13 & 13 & 13 & 11 & 12.5 \\
\hline 腕 & 伸 & 18 & 20 & 18 & 17 & 18 & 17 & 17 & 15 & 18 & 17.5 & 19 & 16 & 15 & 16 & 16.5 \\
\hline
\end{tabular}

\section{III病型による差，性別による差}

Borbèly ${ }^{4}$ ，Jersild，甲田 ${ }^{16}$ ，佐藤・山田等 ${ }^{21)}$ は CR K 性的差異を認めないと述べているが，横関は僅かに女子 低值を報告している。従て健康女子 44 名（16～23才）を 対照とし, L70名（男子15名, 女子 55 名)，N31名（男 子15名，女子16名)，M 17 名（男子7名，女子10名）計 男子37名，女子81名の頖患者の CR を計測した。 $-10 \mathrm{~cm}$ $\mathrm{Hg}$ に抢ける鎖骨窝の海血斑数を測定した結果は Fig. 2 の如く，一般に癩ではC R の減弱がみられるようで出 り，男女差は明らかでなく，幾分男子が弱化するかに見 られる。但し霜患者子健康者と同椂に 2 群に分れて分布 する様相が示された。健康女子では特に高值を示した 5 名は平素から皮膚が負け易かつたり，大理石様皮玟，紫 斑が出来易いとか，毎年涷瘡に罹る者であつた（但し危 険率 $5 \%$ 以下で裹却出来る)。溢血斑数は大体 6 及び 30 の附近に分布するよらである。顧患者ではLは 20 及び
80, Nは 18 及び $68, \mathrm{M}$ は 28 及び 62 の附近に分布し, 分布範囲は $\mathrm{L}>\mathrm{N}>\mathrm{M}$ の順に小さく，しかも Lでは $\mathrm{C} \mathrm{R}$ の極端に強、場合と逆に弱、場合がみられるととは注目 されてよい。 median 及び平均值を算出すると次のよ5 でめる。

\begin{tabular}{c|cc|cc} 
& \multicolumn{2}{|c|}{ 平 } & \multicolumn{2}{|c}{ median } \\
\cline { 2 - 4 } L & $38.8 \pm 31.63$ & $40.3 \pm 29.78$ & 22.4 & 32.6 \\
N & $35.4 \pm 89.49$ & $31.6 \pm 24.50$ & 25.9 & 25.9 \\
M & $50.5 \pm 17.12$ & $45.9 \pm 23.87$ & 53.4 & 45.9
\end{tabular}

III C R の日中の変化

同一人について午前 (9 時), 午後 (15時), 夕刻 (19 時）の 3 回測定するととにより，1 日中の C R の変化を 観察した。健康女子 30 名 (16〜21才) の成績は Tab. 2 に 示す。何れも相当に変動し, 個人差も甚だしいが, 午前 
Fig. 1 灀患者 (LN) のCR 分布

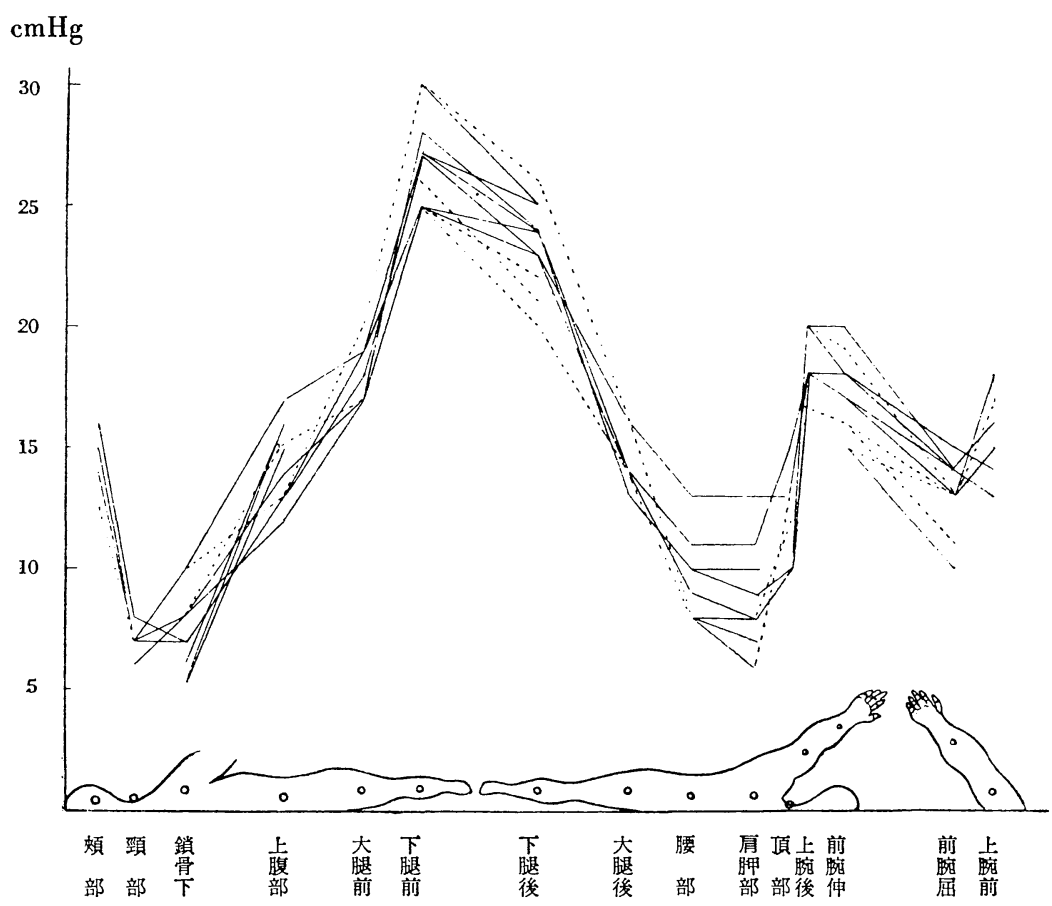

Fig. 2 健康者及び瀨患者の CR 分布

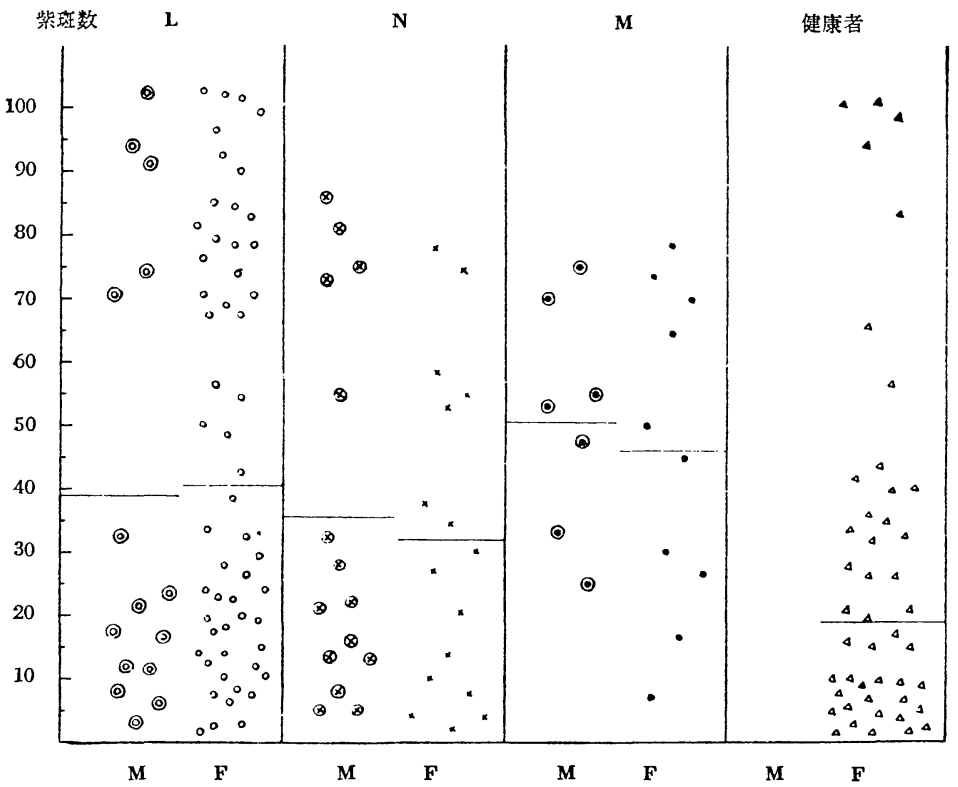


Tab. 2 健唐女子 $\mathrm{CR}$ の日中の変化 $(-10 \mathrm{cmHg}, 1$ 分間)

\begin{tabular}{|c|c|c|c|c|c|c|}
\hline \multirow[t]{2}{*}{ No } & \multicolumn{5}{|c|}{ 測 定 時 間 } & \multirow[t]{2}{*}{ 最大変化 } \\
\hline & 時 & & 5 時 & & 9 時 & \\
\hline 1 & 8 & 21 & $(+13)$ & & $(+17)$ & 17 \\
\hline $\begin{array}{l}2 \\
3\end{array}$ & 8 & 16 & $(+16)$ & 40 & $(+32)$ & 32 \\
\hline & & & & & & 24 \\
\hline 4 & 2 & 12 & $(+10)$ & & $(+3)$ & 10 \\
\hline 5 & 2 & 15 & $(+13)$ & & $(+1)$ & 13 \\
\hline 6 & 4 & 30 & $(+26)$ & & $(+11)$ & 26 \\
\hline 7 & 5 & 21 & $(+16)$ & 18 & $(+13)$ & 16 \\
\hline 8 & 5 & 25 & $(+20)$ & 11 & $(+6)$ & 20 \\
\hline 9 & 6 & 15 & $(+9)$ & 7 & $(+1)$ & 9 \\
\hline 10 & 6 & 20 & $(+14)$ & 14 & $(+8)$ & 14 \\
\hline 11 & 7 & 22 & $(+15)$ & 15 & $(+8)$ & 15 \\
\hline 12 & 8 & 12 & $(+4)$ & 6 & $(-2)$ & 6 \\
\hline 13 & 8 & 30 & $(+22)$ & 17 & $(+9)$ & 22 \\
\hline 14 & 8 & 35 & $(+27)$ & 5 & $(-3)$ & 30 \\
\hline 15 & 9 & 27 & $(+18)$ & 9 & $(0)$ & 18 \\
\hline 16 & 9 & 31 & $(+22)$ & 11 & $(+2)$ & 22 \\
\hline 17 & 10 & 51 & $(+46)$ & 18 & $(+8)$ & 46 \\
\hline 18 & 12 & 56 & $(+44)$ & 15 & $(+3)$ & 44 \\
\hline 19 & 15 & 40 & $(+25)$ & 7 & $(-8)$ & 33 \\
\hline 20 & 17 & 43 & $(+26)$ & 11 & $(-6)$ & 32 \\
\hline 21 & 18 & & $(+3)$ & 11 & $(-7)$ & 10 \\
\hline 22 & 18 & & $(+25)$ & 22 & $(+4)$ & 25 \\
\hline 23 & 20 & & $(+9)$ & 18 & $(-2)$ & 11 \\
\hline 24 & 20 & 35 & $(+15)$ & 22 & $(+2)$ & 15 \\
\hline 25 & 21 & 25 & $(+4)$ & 18 & $(-3)$ & 7 \\
\hline 26 & 21 & 60 & $(+39)$ & 25 & )$+4)$ & 39 \\
\hline 27 & 43 & 100 r & $(+60)$ & 65 & $(+22)$ & $57 \sim$ \\
\hline 28 & 35 & 20 & $(-15)$ & & & 20 \\
\hline 29 & 56 & 21 & $(-35)$ & 16 & $(-40)$ & 40 \\
\hline 30 & 90 & 26 & $(-64)$ & & $(-75)$ & 75 \\
\hline
\end{tabular}

が最も CR が高く,午後に最低を示すものが多い。然し次 第に溢血斑数の減少即ち C R の強化するすのも 3 名むる 午前<午後<夕刻 3 名
午前 $>$ 午後 $<$ 夕刻 24 名

午前 $>$ 午後 $>$ 夕刻 3 名

もし変化の程度を考慮すれば，

午前 $<$ 午後 27 名 $(+3 \sim+60$, 平均 +20.37$)$

午前 >午後 3 名 $(-15 \sim-64$, 平均 -38.00$)$

午前<夕刻 20 名 $(0 \sim+32$, 平均 +8.90$)$

午前>夕刻 10 名 $(-2 \sim-75$, 平均 -16.6$)$

となり, 溢血斑数の差 5 以内を変化なしと判定すれば, 千前が最高のもの11名, 夕刻が最高のもの 6 名, 午前, 夕刻同值のもの13名となる。要するにC Rは午後低下す るが，夜ともなれば午前中の值に復するが，午後の低值 がな㧔るすのも相当むるといえる。これに反し L 患者 15 名についての成樍は (Tab. 3) 変化に富み, CR は

$$
\begin{array}{ll}
\text { 午前<午後<夕刻 } & 2 \text { 名 }(18 \sim 89) \\
\text { 千前<午後>夕刻 } & 4 \text { 名 }(20 \sim 70) \\
\text { 午前 }>\text { 个後 }<\text { 夕刻 } & 6 \text { 名 }(38 \sim 98) \\
\text { 千前 }>\text { 个後>夕刻 } & 3 \text { 名 }(22 \sim 48)
\end{array}
$$

となり, 溢血斑数の差 6 以上を有意と仮定すれば牛前, 夕刻で殆ど変化のないるのは 2 名にすぎず,しかも No. 5 の上5に0〜100 の大きな変化を示するのも岁。従て 最大変化を比較すると健康者の平均25.6（6～75）に対

Fig. 3 健康女子月間の $\mathrm{CR}$ の変化 $(-10 \mathrm{cmHg}, 1$ 分間)

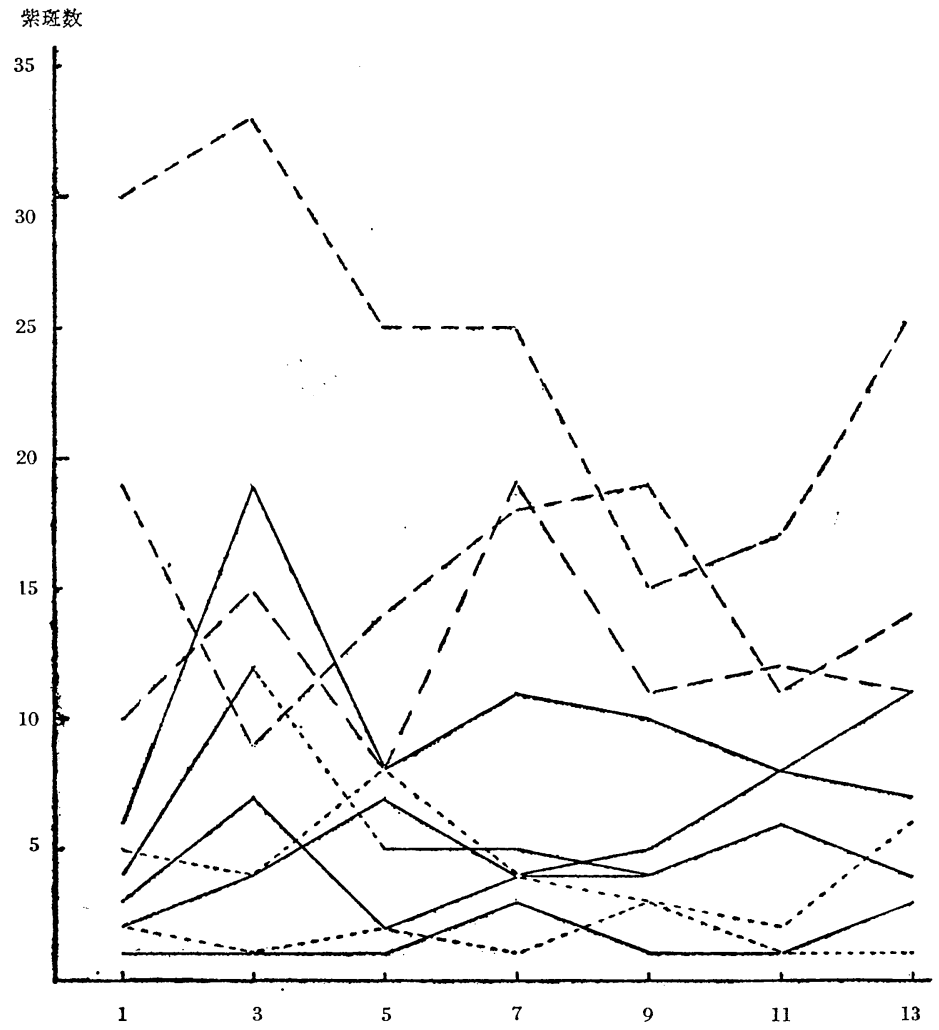


して L 患者では平均55.9（22～98以上）となり，瀨患者 の C Rは日差が著しく大であるといえる。

Tab. 3 L 患者 CR の日中の変化

\begin{tabular}{|c|c|c|c|c|}
\hline \multirow{2}{*}{$\mathrm{No}$ (年令, 性) } & \multicolumn{3}{|c|}{$\begin{array}{llll}\text { 測 定 時 } & \text { 間 } \\
\end{array}$} & \multirow{2}{*}{ 最大変化 } \\
\hline & 9 時 & 15 時 & 19 時 & \\
\hline $\begin{array}{ll}1(41, & \hat{)} \\
2 & 28,\end{array}$ & $\begin{array}{l}7 \\
7\end{array}$ & $\begin{array}{ll}29 & (+22) \\
18 & (+11)\end{array}$ & $\begin{array}{l}55 \\
45\end{array}(+48)$ & $\begin{array}{l}48 \\
38\end{array}$ \\
\hline & 14 & $23(+9)$ & $\begin{array}{ll}45 & (+38) \\
36 & (+22)\end{array}$ & $\begin{array}{l}30 \\
22\end{array}$ \\
\hline $4(41, \hat{\delta})$ & 0 & $57(+57)$ & $22(+22)$ & 57 \\
\hline $5(36, " 1)$ & 2 & $100 \sim(+100)$ & $0(-2)$ & $98 \sim$ \\
\hline $6(28, q)$ & 5 & $\begin{array}{l}48(+43) \\
43(+28)\end{array}$ & $\begin{array}{l}4(-1) \\
5(-10)\end{array}$ & 44 \\
\hline $\begin{array}{l}7(23,0 \\
8(27,0)\end{array}$ & $\begin{array}{l}15 \\
25\end{array}$ & $\begin{array}{l}43(+28) \\
89(+64)\end{array}$ & $\begin{array}{l}(-10) \\
(-25)\end{array}$ & $\begin{array}{l}38 \\
89\end{array}$ \\
\hline $9(34$, \&) & 61 & $100 \sim(+40)$ & $12(-49)$ & $82 \sim$ \\
\hline $10(34, \hat{o})$ & 30 & $10(-20)$ & $14(-1$ & 20 \\
\hline $11(45$, of & 46 & $8(-38)$ & $(-3)$ & 38 \\
\hline $12(37, ")$ & 70 & $4(-66)$ & $9(-61)$ & 66 \\
\hline & & & & \\
\hline $\begin{array}{l}14(20, \\
15(22, ")\end{array}$ & 92 & $31(-61)$ & $3(-$ & 89 \\
\hline
\end{tabular}

\section{C Rの月間の変化}

かつて横関氏は健康男子の月間の変化は測圧法で 0 〜 $2 \mathrm{cmHg}$ 程度であると述べた ${ }^{31)}$ 。従つて私は溢血斑数を 目標にして健康女子10名（16２1才）の月間の変化（昭 和29.2.6〜2.19）を隔日に測定した（Fig. 3)。一般に C $\mathrm{R}$ の低いもの程変動が大きく, 溢血斑数で 3 ～17の範囲 を動摇した。同様に频患者に打いても毎朝06.00〜 07.30 の刻に隔日に検査を行い，約 1 ケ月間（昭29.2.24〜3.2 0）追求すると（鎖骨下部で鎖骨の中央から大体 3 〜 5 $\mathrm{cm}$ の範囲)，男子患者 7 名では（Fig. 4) 一般に CR の 変動が大きく，高血压者（No 1. 2) では溢血斑数で 0〜1 00，正常血压者でも30～90の範国を動摇する。これを通 覽すると大体第 4 日 $(8 / 9)$ 第10日 $(7 / 9)$ 第16日 $(6 / 9)$ 第24

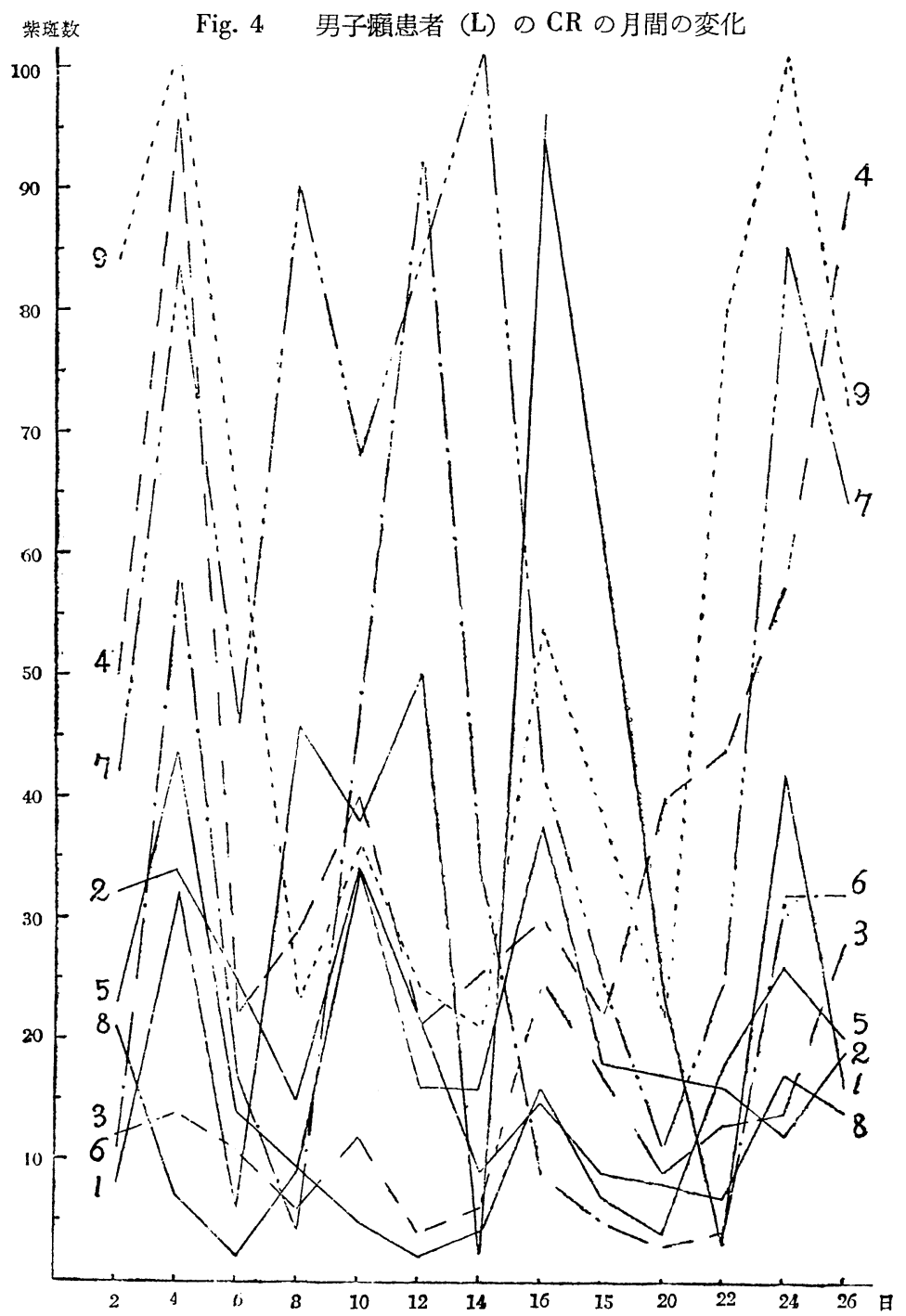


日 $(6 / 9)$ の減弱とその間に於ける増強が見られるが，女 子 4 名は男子に比して変化が不定のよ5に見受けられる

Fig. 5 女子瀨患者 (L) の CR の月間の変化

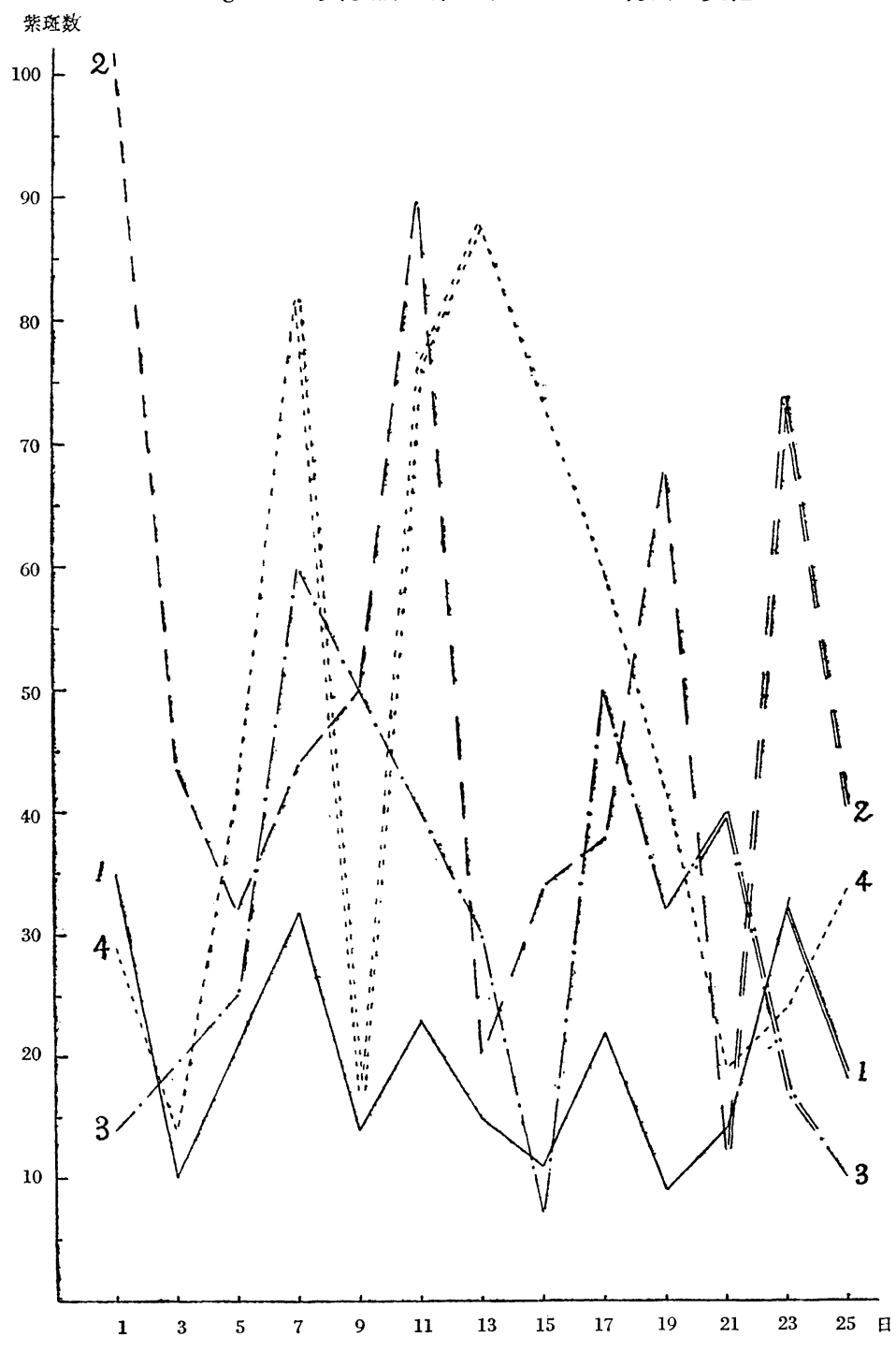

$\mathrm{V}$ 燯性結節性紅斑と C R

急性多発性儿顆性結節性紅斑（以下E N L と略記）を 発生した13例についてC R を測定した成績を Tab. 4 に 示す。 $\mathrm{E} \mathrm{N} \mathrm{L}$ の初期から極期に近うくく至つて C R は著 しく減弱 (61〜100〜) し, 未期に及んで次第に C R の恢 復 (28〜 52) する様想が窺われる。とのととは経過を追 求し得た 7 名の成績にも見られた (Tab. 5)。ENL の発 生から進展につれて C Rが漸次減弱し, 極期《は著しい 減弱を招来し，消褪とともに一過性の増強をへて C R の 恢復が来るるののように思われる。
(Fig. 5)。恐らく横関氏のいらように ${ }^{31)}$ 月経の関係が影 響しよう。 
Tab. 4 ENL 患者の CR

\begin{tabular}{|c|c|c|c|}
\hline 泟例（年令, 性） & 紫玟数 & \multicolumn{2}{|c|}{ （平均） } \\
\hline 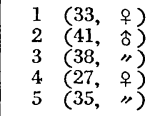 & $\begin{array}{r}0 \\
4 \\
11 \\
18 \\
36\end{array}$ & $\begin{array}{l}0 \\
0 \\
\infty \\
+i \\
\infty \\
\infty \\
-1\end{array}$ & 期 \\
\hline $\begin{array}{lll}6 & (41, & \hat{0}) \\
7 & (28, & \text { + }) \\
8 & (48, & \widehat{\delta}) \\
9 & (51, & \text { " })\end{array}$ & $\begin{array}{c}61 \\
67 \\
100 \text { 以上 } \\
100 \text { 以上 }\end{array}$ & $\begin{array}{l}\overrightarrow{7} \\
\stackrel{\infty}{\infty} \\
\overrightarrow{+}+1 \\
\stackrel{\infty}{\infty}\end{array}$ & 極 \\
\hline $\begin{array}{ll}10 & (27, " \text { " }) \\
11 & (43, ") \\
12 & (54, ") \\
15 & (29, ")\end{array}$ & $\begin{array}{l}28 \\
36 \\
37 \\
52\end{array}$ & $\begin{array}{r}18 \\
+1 \\
+1 \\
\infty \\
\infty \\
\infty\end{array}$ & $\begin{array}{l}\text { 後 } \\
\text { 期 }\end{array}$ \\
\hline
\end{tabular}

Tab. 5 ENL 経過中に颃ける CR の推移

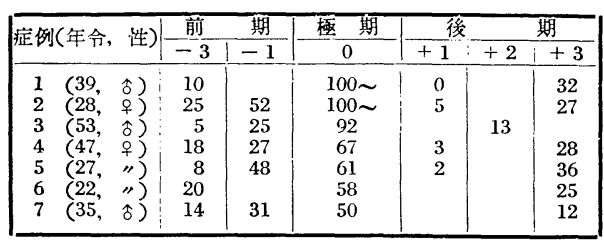

Tab. 6 瀨性神経痛患者の CR

\begin{tabular}{|c|c|c|c|c|}
\hline \multicolumn{2}{|c|}{ 症例（年令, 性） } & 病 & \multicolumn{2}{|c|}{ 紫玫数 (平均) } \\
\hline $\begin{array}{l}1 \\
2 \\
3 \\
4 \\
5 \\
6\end{array}$ & 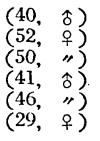 & 强 & $\begin{array}{r}2 \\
2 \\
5 \\
6 \\
28 \\
54\end{array}$ & $\begin{array}{l}\stackrel{20}{-} \\
\stackrel{2}{+1} \\
\stackrel{+1}{-} \\
\stackrel{-}{-1}\end{array}$ \\
\hline $\begin{array}{r}7 \\
8 \\
9 \\
10 \\
11 \\
12 \\
13 \\
14 \\
15 \\
16 \\
17 \\
18 \\
19 \\
20\end{array}$ & 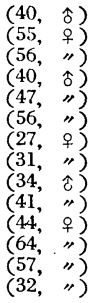 & 期 & $\begin{array}{c}3 \\
4 \\
7 \\
8 \\
8 \\
9 \\
12 \\
15 \\
15 \\
21 \\
27 \\
32 \\
75 \\
100 \sim\end{array}$ & 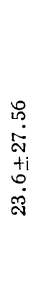 \\
\hline $\begin{array}{l}21 \\
22 \\
23 \\
24 \\
25 \\
26 \\
27\end{array}$ & 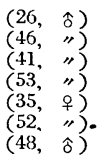 & $\begin{array}{l}\text { 慢 } \\
\text { 性 } \\
\text { 留 } \\
\text { 間 } \\
\text { 蚝 }\end{array}$ & $\begin{array}{c}34 \\
35 \\
48 \\
56 \\
65 \\
100 \sim \\
100 \sim\end{array}$ & 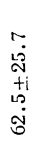 \\
\hline $\begin{array}{l}28 \\
29 \\
30 \\
31 \\
32\end{array}$ & 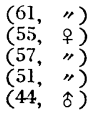 & $\begin{array}{l}\text { 軽 } \\
\text { 快 }\end{array}$ & $\begin{array}{c}3 \\
14 \\
26 \\
32 \\
100 \sim\end{array}$ & $\begin{array}{l}0 \\
\dot{i} \\
+i \\
+i \\
\dot{m} \\
\dot{m}\end{array}$ \\
\hline
\end{tabular}

Tab. 7 Vs 合併㸊费者の CR 分布

\begin{tabular}{|c|c|c|c|}
\hline 紫磷数 & Vs & 㾋対照 & 健康対照 \\
\hline 0 & 2 & & \\
$\sim 10$ & 6 & 9 & 16 \\
$\sim 20$ & 8 & 8 & 9 \\
$\sim 30$ & 2 & 4 & 10 \\
$\sim 40$ & 4 & 2 & 2 \\
$\sim 60$ & 2 & 4 & 1 \\
$\sim 80$ & 2 & 1 & 2 \\
$\sim 100$ & 3 & 2 & \\
$101 \sim$ & 2 & 2 & \\
\hline 䛎 & 31 & 32 & 40 \\
\hline
\end{tabular}

り弱化するが，他の攋患者との間には有意の差を見出す ことが出来なかつた (Tab. 7)。

VIII 攋患者 C R の薬物による変動について

以上により瀬患者の CR が甚だ labil であるととを知 つたので引続いて薬物負荷による变動を摫つた。対象は 結節型の男子 7 名でめる。検查は午前 $7 \sim 8$ 時の間に鎖 骨下部にて行い，注射前の值を皮下ない儿静脈内に薬物 を注射した10〜20分後の值と比較したものである。向溢 血斑数士 5 以内は不变と判定した。

1. ホルモン：藤沢は唯一回の注射により7)，横関は 短期間の連続投与により ${ }^{31)}$ ，CR を高めるホルモンとし て, 甲状腺, 副腎䯣質, 脳下垂体後葉を， C R を低める ホルモンとして膵臓，副腎皮質，脳下垂体前葉，卵胞木 ルモンを挙げている。しかし私の成績は必ずしも両氏の 報告と一致せず，プレホルモンは上昇の，インシュリ ン，インテレニンは低下の傾向にあるが，アトニン，チ ラージンは必ずしす C R を高めないし，オバホルモン， エナルモンはC R に影響が少い上らである (Tab. 8)。

2. ビタミン: Franke, Hartmann, 藤沢6) 等の報告 によれば、 VB1，VB2，VB6 は $\mathrm{CR}$ に殆んど影響なく, $\mathrm{VC}_{\mathrm{B}}$ は CR を高めるよらであるが，横関は $\mathrm{CR}$ がVB1により 影響なく、, $\mathrm{VB} 2, \mathrm{~B} 6, \mathrm{C}$ により高められるとい ${ }^{31)}$ 。私 の場合は VB6は $\mathrm{CR}$ に対し影響少く, VC は低下, 上昇 が殆んど相半ばする状態であつた。

3. 自律神経毒: 甲田 ${ }^{16)}$, 藤沢 ${ }^{6}$ 等が, アトロピンは C R を高め,广セチールコリン，ピロカルピン等は C R を低める如く作用すると述べているが，私の成績ではピ ロカルピンは明らかに C R を低下せしめるに反し，オビ ソートは拈抗的に上昇的に作用した。イミダリンは必ず しも C R を低めないし，アドレナリン，アトロピンす必 ずしも C R を高めるといえず，イミダリンも不定の結果 を示した。

4. その他：横関はヒスタミンによる著しい下降と抗 H剤による上昇を報したが31), 量の関係かエラミンは不 定であり，ネオヒポトニンも同様であつた。横関は B A Lの連用による C R の上昇を報告した ${ }^{31}$ が，八イポンは 不定であり，藤沢が $\mathrm{C} R$ を高めると述べだ゙ スプラクタ 一にはむしろ弱める作用が見られた。

\section{総括並に考按}

荒川教授はかつて皮成機能は常に波状の变動を営み， ことに皮覤の年令的素因, 季節的素因が表明される事を のベられ, 部位的素因の発現には組織解剖的要因を軍視 し, CR が Borbèly のい5分離出来ない皮庴の諸因子の

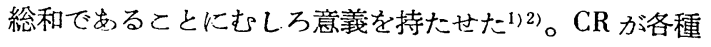


Tab. 8 CR の薬物による变動

\begin{tabular}{|c|c|c|c|c|c|c|c|c|c|c|}
\hline & 薬 & No. 1 & No. 2 & No. 3 & No. 4 & No. 5 & No. 6 & No. 7 & & \\
\hline 1 & プレ $\underset{(500 U)}{*}$ Uン & $23(+21)$ & $32 / 6 \quad(-26)$ & $3 / 19 \quad(+6)$ & ${ }^{100} \sim / 13(-87 \sim)$ & $100 \sim / 73(-27 \sim)$ & $19 / 3 \quad(-16)$ & $75 / 72 \quad(-3)$ & \begin{tabular}{|l|l}
4 & 1
\end{tabular} & \\
\hline 2 & $P \underset{(0.5 \text { c.c. })}{\downarrow}$ & $8 / 39(+31)$ & $(-17)$ & $58 / 15 \quad(-43)$ & $10 / 20 \quad(+10)$ & ${ }^{100} \sim / 90(-10 \sim)$ & $90 / 100 \sim(+10 \sim)$ & $2 / 33 \quad(\div 31)$ & & \\
\hline 3 & 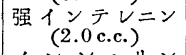 & $12 / 7(-5)$ & $5 / 15 \quad(+10)$ & $37 / 56 \quad(+19)$ & $17 / 46 \quad(+29)$ & $37 / 28 \quad(-19)$ & $(+4)$ & $26 / 50 \quad(+21)$ & 12 & \\
\hline 4 & 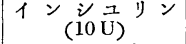 & $1 / 30(+29)$ & $25 / 2 \quad(-23)$ & $(+2)$ & $(+16)$ & $23 / 38 \quad(+15)$ & $(+4)$ & & \begin{tabular}{|l|l|l}
1 & 2 \\
\end{tabular} & \\
\hline 5 & 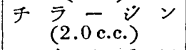 & $15 / 9(-6)$ & $12 / 23 \quad(+11)$ & $76 / 13 \quad(-63)$ & $(+1)$ & $12 / 80 \quad(+68)$ & $(+2)$ & $11 / 21 \quad(+10)$ & & \\
\hline & 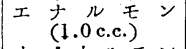 & $17 / 25(+8)$ & $(+13)$ & $40 / 28 \quad(-12)$ & $10 / 10 \quad(\quad 0)$ & $25 / 15 \quad(-10)$ & & $10 / 7 \quad(-3)$ & \begin{tabular}{|l|l|l|}
2 & 2 \\
2
\end{tabular} & \\
\hline & 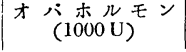 & $7 / 8(+1)$ & $16 / 16 \quad(\quad 0)$ & $10 / 9 \quad(-1)$ & $14 / 16 \quad(+2)$ & $5 / 68 \quad(+63)$ & $26 / 41$ & $20 / 18 \quad(-2)$ & \begin{tabular}{|l|l}
0 & 5 \\
0
\end{tabular} & \\
\hline 8 & & $12(+1)$ & $31 / 32 \quad(+1)$ & ${ }^{100} \sim / 60(-40 \sim)$ & $(+19)$ & $85 / 100 \sim(+15 \sim)$ & $37 / 21 \quad(-16)$ & & & \\
\hline & $\left(\begin{array}{c}\mathrm{C} \\
(100 \mathrm{mg})\end{array}\right.$ & $/ 12(-8)$ & $(-11)$ & $(+7)$ & $(+20)$ & $23 / 61 \quad(+38)$ & $1 / 38$ & ${ }^{100} \sim / 14$ & $\begin{array}{lll}3 & 0\end{array}$ & 0 \\
\hline & $\begin{array}{l}\qquad \vee V ナ リ \\
\qquad(0.5 \text { c.c. })\end{array}$ & $10 / 13(+3)$ & $(-22)$ & $(+42)$ & $75 / 51 \quad(-24)$ & $16 / 25 \quad(+9)$ & $33 / 13 \quad(-17)$ & $7 / 3$ & 32 & 22 \\
\hline & $(0.1 \%, 0.5$ c.c. $)$ & $8 / 15(+7)$ & $75 / 100 \sim(+25 \sim)$ & $90 / 100 \sim(+10 \sim)$ & $56 / 8 \quad(-43)$ & $10 / 3 \quad(-7)$ & $(-31)$ & ${ }^{100} \sim / 65(-3 \overline{5} \sim)$ & 40 & 03 \\
\hline & $\begin{array}{l}\text { ピ口カルビ } \\
(0.1 \%, 0.5 \text { c.c. })\end{array}$ & $14 / 38(+24)$ & $80 / 100 \sim(+20 \sim)$ & $14 / 38 \quad(+24)$ & $66 / 100 \sim(+34 \sim)$ & $28 / 68 \quad(+4.0)$ & $3 / 20$ & $4 / 20 \quad(-16)$ & 00 & 07 \\
\hline & ${ }^{\dagger} \leftarrow_{(0.1 \mathrm{gr})}{ }^{\prime}+$ & $43 / 31(-12)$ & $18 / 49 \quad(+31)$ & $(+28)$ & $37 / 25 \quad(-12)$ & $100 \sim / 90(-10 \sim)$ & $38 / 30$ & ${ }^{103} \sim / 20(-30 \sim)$ & & 01 \\
\hline & 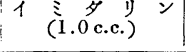 & $12 / 17(+5)$ & $11 / 26 \quad(+15)$ & $11 / 23 \quad(+9)$ & $8 / 21 \quad(+13)$ & $50 / 46 \quad(-4)$ & $33 / 16$ & $100 \sim / 16(-$ & & 22 \\
\hline & × & $11 / 26(+15)$ & $(+3)$ & $(-5)$ & $100 / 71 \quad(-29)$ & $12 / 31$ & $6 / 51$ & & & 22 \\
\hline & $\begin{array}{l}\text { オオーヒポト } \\
(1.0 \text { c.c. })\end{array}$ & $25 / 8(-17)$ & $(-38)$ & $(+9)$ & $23 / 40 \quad(+17)$ & ${ }^{100} \sim / 17(-83 \sim)$ & $22 / 18 \quad(-4)$ & & & \\
\hline & (2 号, 2.0 c.c.c. $)^{2}$ & $16 / 28(+12)$ & $(+7)$ & $(-4)$ & $(-21)$ & $(+23)$ & $(-7)$ & & $\begin{array}{lll}2 & 1\end{array}$ & 1 \\
\hline & 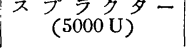 & $7 / 6(-1)$ & $(0)$ & $(+18)$ & $26 / 18 \quad(-8)$ & $(+45)$ & $(\div 20)$ & & & 23 \\
\hline
\end{tabular}

分子は注射前値, 分母は注射後值，（）は両皆の差

疾患, 月経, 植物神経機能或はビタミンの影響その他物 理，化学的因子によつて変動するととはすでに諸家の述 ベて打る如くでむるから，私もかかる観点に立つて，い わしや製 Petechiometer を用いて健康者及び瀨患者の C $\mathrm{R}$ を観察した。共に個体差はかなり強いが，瀨患者の身 体各部の C R はそれぞれ部位に特有の C R を有するとと をみた。即ち頸部最も低く，鎖骨下，肩肺部，頂部，上 腹部と末梢に行くに従て C R は次第に上昇し，さらに四 肢末端に行くに従て高值を示す。健康者について石原は 前額部が最も低いとし，野口，真鍋等は鎖骨下で最低値 を示すといい，横関は頸部最も低く，項部，鎖骨下，上 腹部の順に高值と報告した ${ }^{31}$ 。 $。$ 私の成績は横関の成樍と 類似した傾向を示し，屈側が伸側よと低いととも同様で めつた。横関がいらように露出部の高値は外的刺战の常 時曝䜿による角質肥厚，慣れで説明されよらが，かかる 部位には屡々瀨性神経痛, E N L, 皮筧知覚障碍, 筋肉 並沿学萎縮を惹起し易い事は興味がもる。血行障碍の打 こり易いととが重視されてよい。

瀨患者健康部毛細血管像 (ウルトラパークによる計測) の特徴は動脈脚と静脈脚が著しく弛緩抎張している事で あるが著明な屈曲はなく（宮尾・杉本・本田）瀨病変部 と健康部の毛細血管像には大差がないから神経麻疾の結

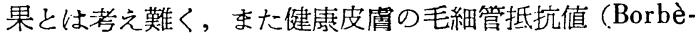
ly 氏法による鎖骨下窝で測定) 恃著しく低下し，50〜13 $5 \mathrm{mmHg}$ で大半は $99 \mathrm{mmHg}$ 以下であり, 病型による差 異は認められないとの報告もある（宮尾・福田） ${ }^{18}$ 。 従 つて部位を一定し，鎖骨下简の值を比較するに健康対照 群に扎いても 2 群に分れた分布を示し，佐藤・山田等が健 康男子について行つた成績21) と同一傾向であつたが，弱 い群は $5 / 44$ にすぎない。然し瀬患者（特こLとNでは C $\mathrm{R}$ の極端に強、場合と弱、場合の数が近似しているとと が特異であり (26：44) 殊にLは分散が最す広く，N, Mの順に分散が小さくなつている。霜の内分泌系に自律 神経機能異常（神宮 ${ }^{10}$ )，沢田），本荘 ${ }^{11)}$ ，緒方 ${ }^{19}$ ，楳木

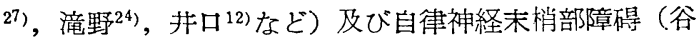
奥23)，藤田 ${ }^{8)}$ ，田尻 ${ }^{25)}$ ，木村，大川なぞ）の毛細血管に 及ぼす器質的ないし機能的影響のむらわれとしてよいで

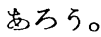

CR に影響する因子として Stern，Bettmann 等は気候 の変異による大気成分の変化を, Mayer et Sulzberger, Urbach 等は食物の影響を力説し, 横関は栄養, 内分泌 機能，中枢神経との関連を系統的に検索した ${ }^{31)}$ 。何れに しても，内的外的因子により，また局所性あるい性全身 性のあらゆる因子に上つて C R :動摇が点らわれると考 
えられるので, 時間的変化を追求すべく, 1 日中の変化 を朝, 昼, 夜の 3 回に分けて計測した。健㡽者の日間変 動は僅少に過ぎす（相目, 露木, 佐藤 ${ }^{21)}$, 横関 ${ }^{21)}$ ) かつ 午後下降しても夕方は殆んど午前と同值に恢復するもの が80\%を占めているに拘らず, 瀨患者 (L) の変動の幅 は健康者の 2 倍に及び $(25: 55)$ 变化の型も各人各様で

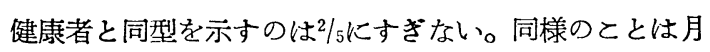
間の変動にも示され, 瀬患者（L）では誠に多彩ですり また甚だ不定であつた。

以上の成績はすべて櫴患者の C R が健庶者のそれに比 べて著しく不安定なととを物語るすのであるが，このと とは薬物投与による影響が必ずしす健康者に見られたと 同じ結果が得られず，むしろ逆の結果が得られたととに よつても知られる。またかかる不安定性は合併症の続発 によりさらに一層高度となる。即ち，E N L の併発によ り, 既に初期か $5 \mathrm{CR}$ Rは減弱し, 極期に最低に達し, 消 褪期に入ると一過性上昇の後に旧に復するものの如くで ある。結節性紅斑の際の C R の低值はすでに横関 ${ }^{21)}$, 藤 沢6) の報告する所であり, との点 E N L も一つのアレル ギー表現型である以上，血管系の機質的障碍の結果とす れば説明は容易でめる。現在神経痛（但しE N Lのよう な随伴症状は除く）に悩む患者（L) の C R が増強し, 夜間特に疼痛の増強があると訴える者では却て昼間值が 減弱しているように思えるが，乙れは恐らく疼痛による 興奮と疲労に伴なら自律神経系の関与が重視されてよい と思われる。

以上要するに瀨患者の C R は一般に低下して打り，し かも甚だ labil であるから，内的或は外的の刺战に対す る反応性が異常であり, 容易に正常な機能閾を冕脱し, 病的症状の顕現が容易になるものと考えられる。換言す れば瀨患者の罹患性が大でむることは C R の面からも窥 い知るととが出来る。

\section{結語}

1. 瀨患者の C R 全身分布を全身15ヶ所について計測 すると, 健康者と同様に頸部, 頂部が最低で末梢に赴く につれ次第に高、（頸部く鎖骨下及び肩胛部く頂＜腰部 ＜顔面及び上腹＜四肢）下肢は上肢より高く, 一般に屈 側が伸側より低い。

2. 鎖骨下部の $\mathrm{C} \mathrm{R}$ の平均值は健康者 $>\mathrm{N}>\mathrm{L}>\mathrm{M}$ の 順であるが， L N 何れも 2 群に分かれ, 分散は L 最も大 きく, $\mathrm{N}, \mathrm{M}$ の順に小さくなる。特に $\mathrm{L}$ の場合 $\mathrm{C} \mathrm{R}$ の增 強する場合と減弱する場合が明かに分け得るのは注目す ベきである。
3. 1 日中の C R の変化は健康人では午後最低を示す ものが $80 \%$ 占めるが，顆患者では $40 \%$ にすぎず，午前 最低型 $(40 \%)$ ，夜間最低型（20\%）など一定しない。

4. 月間の C R の変化は健康者に比へて瀨患者では変 動が大である。

5. E N L の合併により C R は低下するが，極期には 最も減弱して, 消褪期に入ると一過性上昇をへて漸次恢 復する。

6. 神経痛の際には C R の増強がある。但し夜間特に 増強する者では昼間減弱している。

7. 瀨患者に対する薬物負荷による C R の変動は必ず しも健康者と同じでない。即ちプレボルモンは C R を 高めるが, インシユリン，強力インテレニンは $\mathrm{C} \mathrm{R}$ を低 める。アトニン, チラージン, オバホルモン, エナルモ ンの影響は弱い。ビタミン C, B6 の影響は不定である。 ピロカルピンは C R を低め, オビソートは C R を強める が,アドレナリン, イミダリン，アトロピンは高低相半 ばした。ネオヒポトニンは上昇的であり，エラミン，、 イポンは高低相半ばし、スプラクターはむしろ弱化せし めた。

（本論文の要旨は昭和 29 年 12 月四国皮泌科地方会及び 岡山皮泌科地方会に扔いて分割発表した。稿を終るに当 り御懇切なる御指導と御校閲を賜つた恩師荒川教授並に 野島園長深謝の意を表する。な打御協力を戴いた藤川 澄子，木村扶省子の両氏に感謝する)。

\section{参 考 文 献}

1. 荒川忠良：皮性誌. 62 (4), 65 (昭27)

2. 荒川忠良, 他: 最近医学. 7 (11), 89 (昭27)

3. Benneke: münch. med. wsch. 58. 740 (1911)

4. Borbély : munch. med. wsch. 21. 886 (1930)

5. 古川 明: 医療. 6 ( 7), 45 (昭27)

6. 藤沢勝久: 皮性誌. 63 (2), 85 (昭 28)

63 (8)，495 (昭28)

63 (9), 555 (昭28)

7. 福田 実: レプラ. 20 (5), 153 (昭26)

8. 藤田恵一：レプラ. 22 (4), 199 (昭28)

9. 郷野博雄: 皮と必. 16 (1)，41（昭29）

10. 神宮良一, 他: レプラ. 22 ( 5), 150 (昭28)

11. 本荘賢治：レプラ. 22 (4)，200（昭28）

12. 井口曰広：レプラ. 24 (1)，47 (昭30)

13. 井口曰広, 他: レプラ. 23 (4)，204（昭29）

14. 伊藤実: 医学叢書. 皮唐科のアレルギー（昭25）

15. Köhn: Arch. Dermat. 171, 125 (1935) 
16. 甲田勝夫：東北医誌. 42, 131 (昭26）

17. Leede : münch. med. wsch. 58, 293 (1911)

18. 宮尾定信，他：レプラ. 22 (4)，199（昭28）

19. 緒方惟弘：レプラ. 22 (4), 158 (昭28)

20. Rupp: J. Clin. Endocrin. 11, 688 (1951)

21. 佐藤・山田：診断と治療. 26 (2), 61 (昭26)

22. 戸塚・島内：日内会誌. 30 (9), 585 (昭17)

23. 谷奥喜平：皮性誌. $63(7), 403$ (昭28)

24. 滰野増市：レプラ. 2 (1), 33 (昭 6)

25. 田尻 敢：レプラ. 22 (4), 199 (昭28)
26. 宇都宮・井口, 他：レプラ. 24 (1), 1 (昭30)

27. 楳木旺栄：レプラ. 22 (4)，200(昭28)

28. Völgyessy: Arch. Dermat. 179, 387 (1939)

29. 和気一寿: レプラ. 22 (4)，200 (昭28)

30. 吉永敏夫：レプラ. 21 (2), 41 (昭 27)

31. 横関 勤: 皮性誌. 62 (4), 72 (昭 28)

四国医誌. 6 ( 3 ), 4l (昭30)

7 (2)，80，91（昭30）

7 (3), 163 (昭 30$)$ 